\title{
An Analysis for Distribution of Natural Radionuclides in Soil, Sand and Sediment of Potenga Sea Beach Area of Chittagong, Bangladesh
}

\author{
Sabina Yasmin 1,2, Bijoy Sonker Barua², Masud Kamal², Md. Abdur Rashid ${ }^{1}$ \\ ${ }^{1}$ Department of Physics, Chittagong University of Engineering and Technology, Chittagong, Bangladesh \\ ${ }^{2}$ Atomic Energy Centre, Bangladesh Atomic Energy Commission, Chittagong, Bangladesh \\ Email: sabinayasmin309@gmail.com
}

Received 15 September 2014; revised 12 October 2014; accepted 5 November 2014

Copyright (C) 2014 by authors and Scientific Research Publishing Inc.

This work is licensed under the Creative Commons Attribution International License (CC BY). http://creativecommons.org/licenses/by/4.0/

(c) (i) Open Access

\begin{abstract}
A HPGe (High Purity Germanium) detector based, low background gamma-ray counting system was used for activity measurement in soil, sand and sediment samples collected from Potenga sea beach area of Chittagong, Bangladesh. The specific radioactivities of Radium $\left.{ }^{226} \mathrm{Ra}\right)$, Thorium $\left({ }^{232} \mathrm{Th}\right)$ and Potassium $\left({ }^{40} \mathrm{~K}\right)$ were measured in the above samples. The investigation reflects the lower deposition of minerals exist in the collected samples. From the measured specific radioactivities of the above three natural radionuclides, the radium equivalent activity $\left(\mathrm{Ra}_{\mathrm{eq}}\right)$, the external hazard index $\left(H_{\mathrm{ex}}\right)$, the external gamma absorbed dose rate and the annual effective dose were calculated. The obtained mean values of gamma absorbed dose rate in soil and sand samples and annual effective dose in soil, sand and sediment samples were found higher than the worldwide average as reported by United Nations Scientific Committee on the Effects of Atomic Radiation (UNSCEAR, 2000). The $\mathrm{Ra}_{\mathrm{eq}}$ values were in the range of 47.86 to $293.76 \mathrm{~Bq} \cdot \mathrm{kg}^{-1}$ and the $H_{\mathrm{ex}}$ varied from $0.13-0.81$, which indicated that the study area was radiologically safe for human being.
\end{abstract}

\section{Keywords}

Natural Radioactivity, Specific Radioactivity, HPGe $\gamma$-Ray Detector, Radiation Hazard Index, Dose Rate, Potenga Sea Beach

\section{Introduction}

Radioactive elements that are found in nature can be placed in three general categories, namely cosmogenic, 
primordial and anthropogenic. The high energy primary cosmic radiation induces various complex interactions with the earth's atmosphere, and results to cosmogenic radionuclides and hence produces secondary radiation [1]. However, only a part of these radiations reach the earth's surface because the earth atmosphere acts as a filter and absorbs much of the energy of the cosmic rays. Primordial radionuclides which are left on earth since its creation, dominate in the wider environment such as in all types of soil, rocks, water, air, building materials, food and the human body [2]. On the point of contribution to radiation dose received by mankind, the most important primordial radionuclides are uranium series, thorium series and ${ }^{40} \mathrm{~K}$ [3]. Of our daily life concern, the concentration of NORM (Naturally Occurring Radioactive Materials) which is characterised by cosmogenic and primordial can be increased above the natural background levels through specific industrial activities such as waste products of sludge etc. [4], and higher utilization of computed tomography (CT) and nuclear medicine [5]. Therefore, without these artificial sources our annual background doses do not change significantly.

However, radioactive materials are subjected to ionizing radiation, which has sufficient energy to break some chemical bonds. Any living tissue in the human body can be damaged by ionizing radiation in a unique manner. The body attempts to repair the damage, but sometimes it is too widespread that the damage cannot be repaired and causes cancerous cells.

Potenga sea beach of Chittagong district has unique natural characteristics and is an ideal place to visit. Year after year, many kinds of organic and inorganic materials from the food and containers that are left behind by the tourist are accumulated and distributed to this area. Moreover, the activity levels vary greatly depending on soil type, mineral make-up and density. Higher levels of activity are usually associated with igneous and metamorphic rocks. Beach sand or soil is mineral deposits formed through the weathering and erosion of these kinds of rocks. Some constituent minerals of different concentration within the sand contain natural radionuclides [6]. The nuclear weapon testing of some neighborhood countries may also elevate the level of natural radioactivity in environment. Therefore, the measurement of natural radioactivity and artificial radioactivity due to gamma rays from this place should be regularly examined. In the present study the knowledge of specific activities and distributions of ${ }^{238} \mathrm{U}\left({ }^{226} \mathrm{Ra}\right),{ }^{232} \mathrm{Th},{ }^{40} \mathrm{~K}$ and ${ }^{137} \mathrm{Cs}$ in soil, sand and sediment samples collected from Potenga sea beach area were of interest since it provided useful information for estimation of the radiation exposures of human being and in monitoring of environmental radioactivity at that area.

\section{Materials and Method}

\subsection{Sample Collection}

A number of soil, sand and sediment samples were collected from sea beach area of Potenga, Chittagong. Sediment samples (Sb-L-21 to Sb-L-30) were under the shallow sea water and the sand samples (Sb-L-11 to Sb-L-20) are frequently inundated by sea water. The sampling locations are identified as L1-L30 in Figure 1. The studied area along the bank of the Bay of Bengal is located in Potenga, Chittagong, Bangladesh. It lies between the

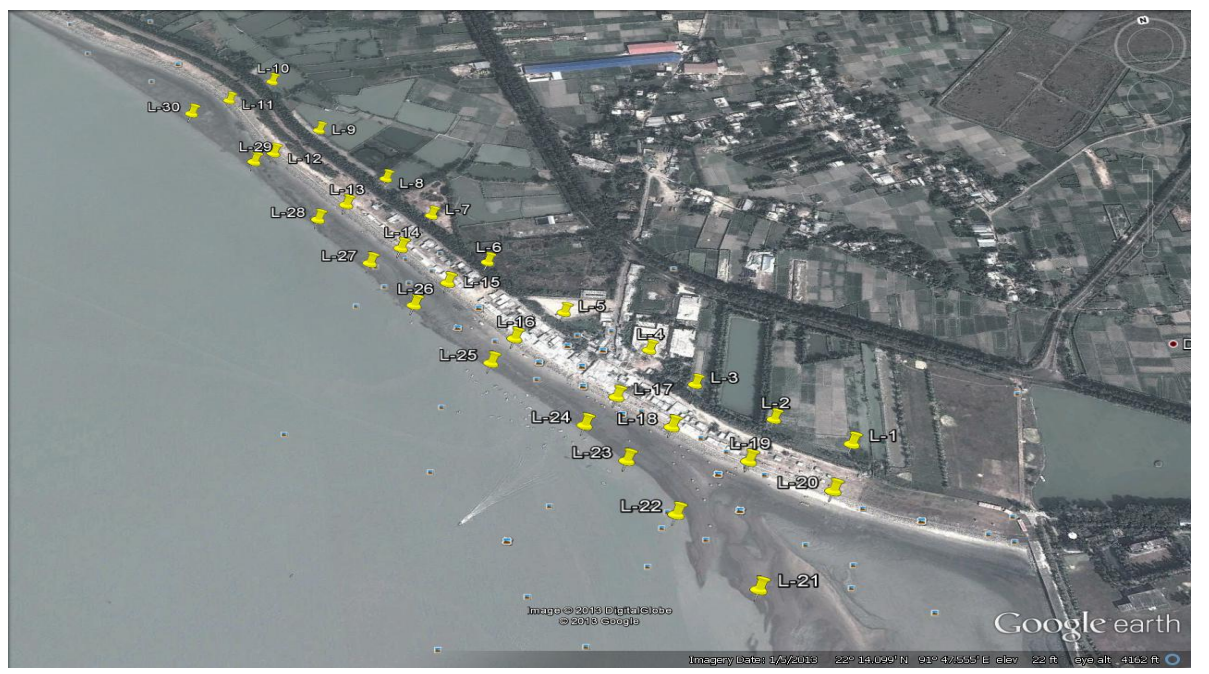

Figure 1. The map showing sampling locations (L-1 to L-30) in Potenga sea beach, Chittagong, Bangladesh. 
longitudes of $91^{\circ} 47.245^{\prime}-91^{\circ} 47.710^{\prime}$ and the latitudes of $22^{\circ} 14.440^{\prime}-22^{\circ} 13.950^{\prime}$. At every location the sample was collected from 5 - $10 \mathrm{~cm}$ depth. All investigated locations were along a line from north to south and formed three adjacent rows. Each sample was about $101 \mathrm{~m}$ apart from the nearest one and kept in a plastic bag and labeled according to the location.

\subsection{Sample Preparation for $\gamma$-Ray Spectrometry}

All investigated samples were dried under the direct sunlight for several days to evaporate the water. After removing unwanted objects each sample was also oven dried at about $105^{\circ} \mathrm{C}$ to obtain constant weight. The investigated samples finally collected after passing through a $500 \mu \mathrm{m}$ sieve to ensure the homogeneity of the sample. For the measurement of natural radioactivity, each dried sample was weighed and then taken into individual cylindrical plastic container of $8 \mathrm{~cm}$ diameter and $2.8 \mathrm{~cm}$ height. The sample in container was simply shaken by hand to allow the powder to settle down homogeneously. The volume of the soil sample amounting to about 131 $\mathrm{cm}^{3}$ was kept equal to the standard $\gamma$-ray source material. The containers were sealed tightly and wrapped with thick vinyl tapes around their screw necks to keep air tight. These samples were stored for minimum four weeks before the measurement of radioactivity to allow for the attainment of secular equilibrium between ${ }^{226} \mathrm{Ra}$ and ${ }^{232}$ Th and their progeny [7] [8].

\subsection{Radioactivity Measurements}

\subsubsection{Measurement Setup}

The radioactivities of the prepared samples and International Atomic Energy Agency (IAEA) reference samples of the same geometry were measured by using a closed-end coaxial high-purity germanium (HPGe) $\gamma$-ray detector with a relative efficiency of $20 \%$, resolution $1.8 \mathrm{keV}$ (FWHM) at $1332 \mathrm{keV}$ of ${ }^{60} \mathrm{Co}$. The HPGe $\gamma$-ray detector (GC2018, CANBERRA, USA) was coupled with digital spectrum analyzer, DSA-1000 at the Radioactivity Testing and Monitoring Laboratory, Atomic Energy Center, Chittagong, Bangladesh. The system architecture shown in Figure 2 has been frequently used to measure radioactivity of bulky samples. The detector was well shielded to minimize the $\gamma$-ray background to be able to measure low radioactivity. The shielding consists of a cylindrical $5.08 \mathrm{~cm}$ thick lead with a fix bottom and removable cover. Due to low activity, each sample was measured at position of surface of the detector within the shielding arrangement [9]. The $\gamma$-ray spectra were taken and analyzed by using the program GENIE 2000. Counting time interval was 10,000 seconds. To determine the radioactivity of the natural radioisotopes, sample counts with specific energies as well as background counts were taken accordingly. Background count was determined by a blank plastic container of the same geometry of the sample. All the background counts were subtracted from original sample counts to obtain the net peak areas. The net peak area in a $\gamma$-ray spectrum represents the number of counts collected for only that $\gamma$-ray energy of a radioisotope present in the sample. These peak areas are used to determine the radioactivity concentration of radionuclides present in the sample.

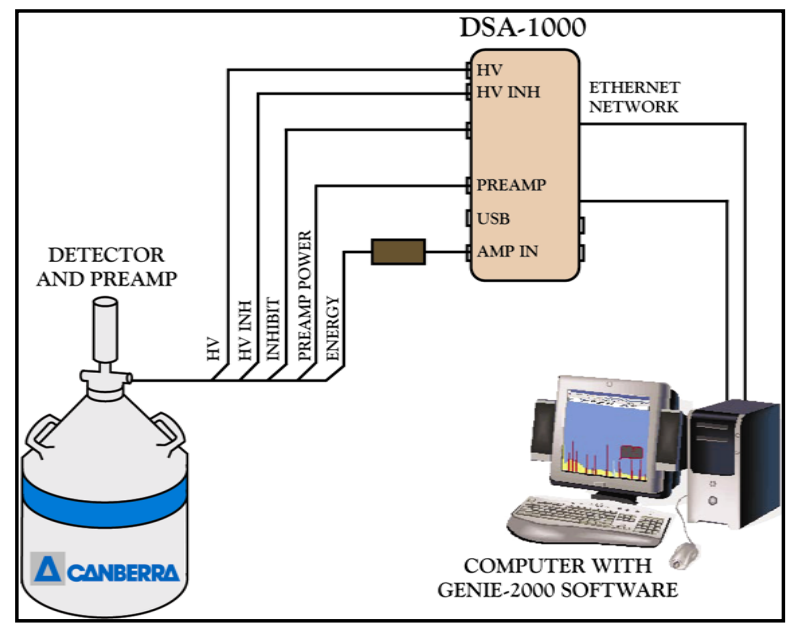

Figure 2. Gamma spectroscopy system architecture. 


\subsubsection{HPGe $\gamma$-Ray Detector Efficiency}

The detector efficiency is an important factor for the measurement of bulk material because it depends on volume as well as on distance of the sample. In the present work a reliable efficiency vs energy curve for the HPGe $\gamma$-ray detector was determined by measuring the known activity of the volume uranium standard reference material (RGU-1), thorium standard reference material (RGTh-1) and potassium standard reference material (RGK-1) provided by the IAEA, Vienna [10]. The standard radioactive sources have geometry similar to the investigated samples. Both the IAEA-RGU-1 and IAEA-RGTh-1 radioactive powder reference materials prepared by dilution of a uranium ore and thorium ore with floated silica powder of similar grain size distribution, respectively, were provided by the IAEA. ${ }^{226} \mathrm{Ra}$ and ${ }^{210} \mathrm{~Pb}$ are confirmed to be in radioactive equilibrium and no evidence for inhomogeneity was detected after mixing and bottling. By the sample-detector distance and the solid angle subtended by the sample, the random coincidence loss became negligible, because sample geometry is similar to standard radioactive sources used for efficiency calibration. These three standards $\gamma$-ray sources of same volume were used to generate efficiency versus energy curve for the HPGe $\gamma$-ray detector. The obtained efficiency versus energy curve is shown in Figure 3.

\subsubsection{Data Analysis}

The peaks of $\gamma$-ray spectrum found each of the investigation sample are attributed to the decay products of ${ }^{238} U$ and ${ }^{232} \mathrm{Th}$ series and to ${ }^{40} \mathrm{~K}$. The ${ }^{226} \mathrm{Ra}\left({ }^{238} \mathrm{U}\right)$ activity was determined individually from the net area of peak at energies of $351.9 \mathrm{keV}$ (due to ${ }^{214} \mathrm{~Pb}$ ) and $609.31 \mathrm{keV}$ (due to ${ }^{214} \mathrm{Bi}$ ). Similarly, the counts at peak energies of $238.6 \mathrm{keV}\left({ }^{212} \mathrm{~Pb}\right)$ and $911 \mathrm{keV}\left({ }^{228} \mathrm{Ac}\right)$ were used to determine the ${ }^{232} \mathrm{Th}$ activity. Finally, we took average of the values obtained from different peak energies. The activity of ${ }^{40} \mathrm{~K}$ was determined from its $1460.83 \mathrm{keV} \gamma$-line. It should be mentioned that no peak appeared at energy of $661 \mathrm{keV}$ in the spectrum due to decay of ${ }^{137} \mathrm{Cs}$ and it confirms that the artificial radioactivity in the investigated samples is below the detection limit.

From the measured gamma-ray count rate (CPS), the activity concentration of the ${ }^{226} \mathrm{Ra}$, ${ }^{232} \mathrm{Th}$ and ${ }^{40} \mathrm{~K}$ radionuclides were calculated by the following formula

$$
A=(\mathrm{CPS} \times 1000) /(\varepsilon \times I \gamma \times M)
$$

where, $A$ represents the specific activity $\left(\mathrm{Bq} \cdot \mathrm{kg}^{-1}\right), \varepsilon$ is the efficiency of the detector for the corresponding peak, $I \gamma$ is the gamma-ray emission probability and $M$ is the mass of the sample in gramme.

The standard deviation for the error measurement has been expressed as

$$
\mathrm{SD}, \sigma=\left(\frac{\left(x_{1}-\bar{x}\right)^{2}+\left(x_{2}-\bar{x}\right)^{2}+\cdots+\left(x_{n}-\bar{x}\right)^{2}}{n}\right)^{1 / 2} \text {. }
$$

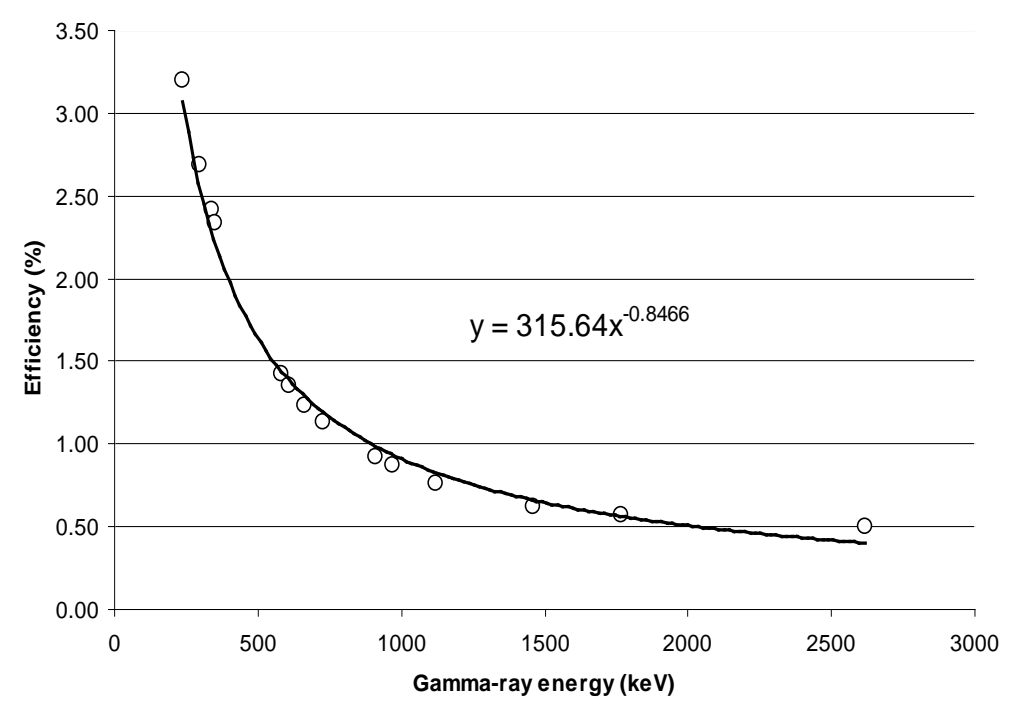

Figure 3. Efficiency vs energy curve for HPGe $\gamma$-ray detector. 


\subsection{Radiation Hazard Index and Dose Rate Calculation}

The most widely used radiation hazard index is called the radium equivalent activity. The exposure due to the gamma radiation in terms of radium equivalent activity $\mathrm{Ra}_{\mathrm{eq}}$ has been calculated using the following equation [11]:

$$
\mathrm{Ra}_{\mathrm{eq}}=C_{\mathrm{Ra}}+1.43 C_{\mathrm{Th}}+0.07 C_{\mathrm{K}}
$$

where $C_{\mathrm{Ra}}, C_{\mathrm{Th}}$ and $C_{\mathrm{K}}$ are the specific activities $\left(\mathrm{Bq} \cdot \mathrm{kg}^{-1}\right)$ of ${ }^{226} \mathrm{Ra},{ }^{232} \mathrm{Th}$ and ${ }^{40} \mathrm{~K}$, respectively. Here, it is assumed that $370 \mathrm{~Bq} \cdot \mathrm{kg}^{-1}$ of ${ }^{226} \mathrm{Ra}$ or $259 \mathrm{~Bq} \cdot \mathrm{kg}^{-1}$ of ${ }^{232} \mathrm{Th}$ or $4810 \mathrm{~Bq} \cdot \mathrm{kg}^{-1}$ of ${ }^{40} \mathrm{~K}$ produce the same gamma dose rate. The value of $370 \mathrm{~Bq} \cdot \mathrm{kg}^{-1}$ is allowed as a maximum value for public dose considerations [11].

In order to measure the radiation hazards, the external hazard index, $H_{\mathrm{ex}}$, is defined as [11]:

$$
H_{\text {ex }}=C_{\mathrm{Ra}} / 370+C_{\mathrm{Th}} / 259+C_{\mathrm{K}} / 4810
$$

The value of this index must be less than unity in order to keep the radiation hazard insignificant. The maximum value of $H_{\mathrm{ex}}$ equal to unity corresponds to the upper limit of radium equivalent activity $\left(370 \mathrm{~Bq} \cdot \mathrm{kg}^{-1}\right)$.

The external gamma absorbed dose rate due to terrestrial $\gamma$-rays in the air at $1 \mathrm{~m}$ above ground level was calculated from the measured activities of ${ }^{226} \mathrm{Ra},{ }^{232} \mathrm{Th}$ and ${ }^{40} \mathrm{~K}$ in the soil, sand and sediment samples. The calculations were performed according to the following equation [12]:

$$
D=0.462 C_{\mathrm{Ra}}+0.604 C_{\mathrm{Th}}+0.042 C_{\mathrm{K}}
$$

where, $D$ is the dose rate in $\mathrm{nGy} \cdot \mathrm{h}^{-1}$. About $98 \%$ of the external gamma dose rate from the ${ }^{238} \mathrm{U}$ series is delivered by the ${ }^{226} \mathrm{Ra}$ subseries. So disequilibrium between ${ }^{226} \mathrm{Ra}$ and ${ }^{238} \mathrm{U}$ will not affect the dose estimation from the measurement of ${ }^{226} \mathrm{Ra}$. In the above equation, it is assumed that all decay products of ${ }^{226} \mathrm{Ra}$ and ${ }^{232} \mathrm{Th}$ are in radioactive equilibrium with their precursors.

To estimate the annual effective dose, the conversion factor of $0.7 \mathrm{~Sv} / \mathrm{Gy}$ from absorbed dose rate in air to effective dose received by adults and the indoor occupancy factor must be taken into account. Considering that people in the sea beach area of Potenga, on the average, spent $40 \%$ of their time outdoors. The annual effective doses were calculated as follows [12]:

$$
\text { Annual effective dose }(\mathrm{Sv})=D \times 24 \times 365 \times 0.7 \times 0.4 \text {. }
$$

\section{Results and Discussions}

\subsection{Specific Activities}

The measured specific activities of the natural radionuclides ${ }^{226} \mathrm{Ra}\left({ }^{238} \mathrm{U}\right),{ }^{232} \mathrm{Th}$ and ${ }^{40} \mathrm{~K}$ in soil, sand and sediment samples are given in Table 1, together with the standard deviation from the several values and their average for a radionuclide. The activity ratios of ${ }^{232} \mathrm{Th}$ and ${ }^{226} \mathrm{Ra}$ are also given in Table 1 . The corresponding charts are shown in Figures 4-7. The ${ }^{226} \mathrm{Ra},{ }^{232} \mathrm{Th}$ and ${ }^{40} \mathrm{~K}$ radioactivities in soil samples are varied in the range of

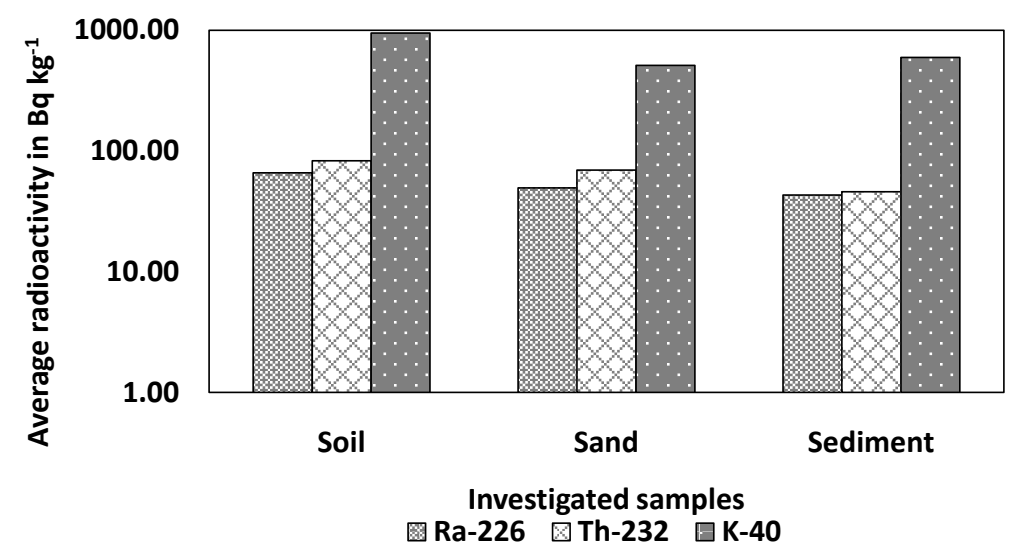

Figure 4. Comparison of the measured mean specific activities of natural radionuclides among the investigated samples. 
Table 1. Measured specific radio activities due to ${ }^{226} \mathrm{Ra},{ }^{232} \mathrm{Th}$ and ${ }^{40} \mathrm{~K}$ in the investigated samples collected form Potenga sea beach area of Chittagong.

\begin{tabular}{|c|c|c|c|c|c|c|c|}
\hline \multicolumn{7}{|c|}{ Measured specific radioactivity of dry samples $\left(\mathrm{Bq} \cdot \mathrm{kg}^{-1}\right)$} & \multirow{2}{*}{$\begin{array}{l}\mathrm{Th} / \mathrm{Ra} \\
\text { ratio }\end{array}$} \\
\hline Sample ID & ${ }^{226} \mathrm{Ra}$ & $\mathrm{SD} \%$ & ${ }^{232} \mathrm{Th}$ & $\mathrm{SD} \%$ & ${ }^{40} \mathrm{~K}$ & $\mathrm{SD} \%$ & \\
\hline \multicolumn{8}{|c|}{ Soil samples } \\
\hline SB-L-1 & 86.12 & 6.72 & 92.64 & 5.15 & 1073.77 & 4.23 & 1.08 \\
\hline SB-L-2 & 59.73 & 3.98 & 88.51 & 1.06 & 789.54 & 5.45 & 1.48 \\
\hline SB-L-3 & 73.01 & 5.45 & 82.17 & 4.31 & 1125.40 & 6.34 & 1.13 \\
\hline SB-L-4 & 50.68 & 5.41 & 85.56 & 3.08 & 1089.72 & 4.23 & 1.69 \\
\hline SB-L-5 & 84.56 & 6.49 & 99.80 & 3.83 & 859.51 & 7.24 & 1.18 \\
\hline SB-L-6 & 67.29 & 7.14 & 102.64 & 5.68 & 879.27 & 5.64 & 1.53 \\
\hline SB-L-7 & 72.32 & 4.03 & 67.39 & 7.45 & 942.87 & 5.21 & 0.93 \\
\hline SB-L-8 & 70.41 & 3.96 & 74.99 & 3.60 & 824.31 & 6.45 & 1.07 \\
\hline SB-L-9 & 41.52 & 7.27 & 69.30 & 8.95 & 1097.68 & 6.23 & 1.67 \\
\hline SB-L-10 & 53.40 & 6.90 & 68.65 & 5.18 & 787.51 & 7.56 & 1.29 \\
\hline Average & 65.90 & 5.74 & 83.17 & 4.83 & 946.96 & 5.86 & 1.30 \\
\hline \multicolumn{8}{|c|}{ Sand samples } \\
\hline SB-L-11 & 77.84 & 7.01 & 95.29 & 9.19 & 624.55 & 5.73 & 1.22 \\
\hline SB-L-12 & 29.75 & 12.42 & 73.37 & 3.58 & 451.45 & 4.37 & 2.47 \\
\hline SB-L-13 & 27.82 & 9.71 & 45.77 & 3.00 & 510.58 & 3.25 & 1.65 \\
\hline SB-L-14 & 71.87 & 1.36 & 84.82 & 0.73 & 401.83 & 6.82 & 1.18 \\
\hline SB-L-15 & 28.21 & 2.49 & 38.43 & 8.34 & 456.79 & 4.31 & 1.36 \\
\hline SB-L-16 & 34.89 & 8.29 & 64.17 & 1.09 & 626.18 & 3.24 & 1.84 \\
\hline SB-L-17 & 48.12 & 4.50 & 58.17 & 2.93 & 416.04 & 6.54 & 1.21 \\
\hline SB-L-18 & 62.89 & 5.49 & 88.81 & 3.64 & 404.83 & 4.52 & 1.41 \\
\hline SB-L-19 & 89.12 & 2.73 & 98.59 & 2.47 & 649.22 & 3.67 & 1.11 \\
\hline SB-L-20 & 24.72 & 9.92 & 47.45 & 2.09 & 580.45 & 5.35 & 1.92 \\
\hline Average & 49.52 & 6.39 & 69.49 & 3.71 & 512.19 & 4.78 & 1.54 \\
\hline \multicolumn{8}{|c|}{ Sediment samples } \\
\hline SB-L-21 & 28.56 & 2.40 & 46.80 & 4.45 & 585.71 & 4.76 & 1.64 \\
\hline SB-L-22 & 57.08 & 4.22 & 54.24 & 1.07 & 542.38 & 6.75 & 0.95 \\
\hline SB-L-23 & 65.41 & 4.72 & 87.59 & 1.99 & 654.94 & 5.36 & 1.34 \\
\hline SB-L-24 & 17.09 & 7.44 & 25.91 & 1.24 & $\mathrm{bd}^{*}$ & bd & 1.52 \\
\hline SB-L-25 & 49.27 & 5.24 & 40.93 & 2.70 & bd & bd & 0.83 \\
\hline SB-L-26 & 67.10 & 3.41 & 67.79 & 1.73 & bd & bd & 1.01 \\
\hline SB-L-27 & 23.69 & 6.73 & 16.90 & 3.97 & bd & bd & 0.71 \\
\hline SB-L-28 & 21.95 & 1.03 & 25.26 & 4.81 & bd & bd & 1.15 \\
\hline SB-L-29 & 55.39 & 3.75 & 16.14 & 4.77 & bd & bd & 0.29 \\
\hline SB-L-30 & 46.68 & 3.10 & 76.99 & 0.68 & bd & bd & 1.65 \\
\hline Average & 43.22 & 4.20 & 45.85 & 2.74 & 594.34 & 5.62 & 1.11 \\
\hline
\end{tabular}

*bd = below detection. 

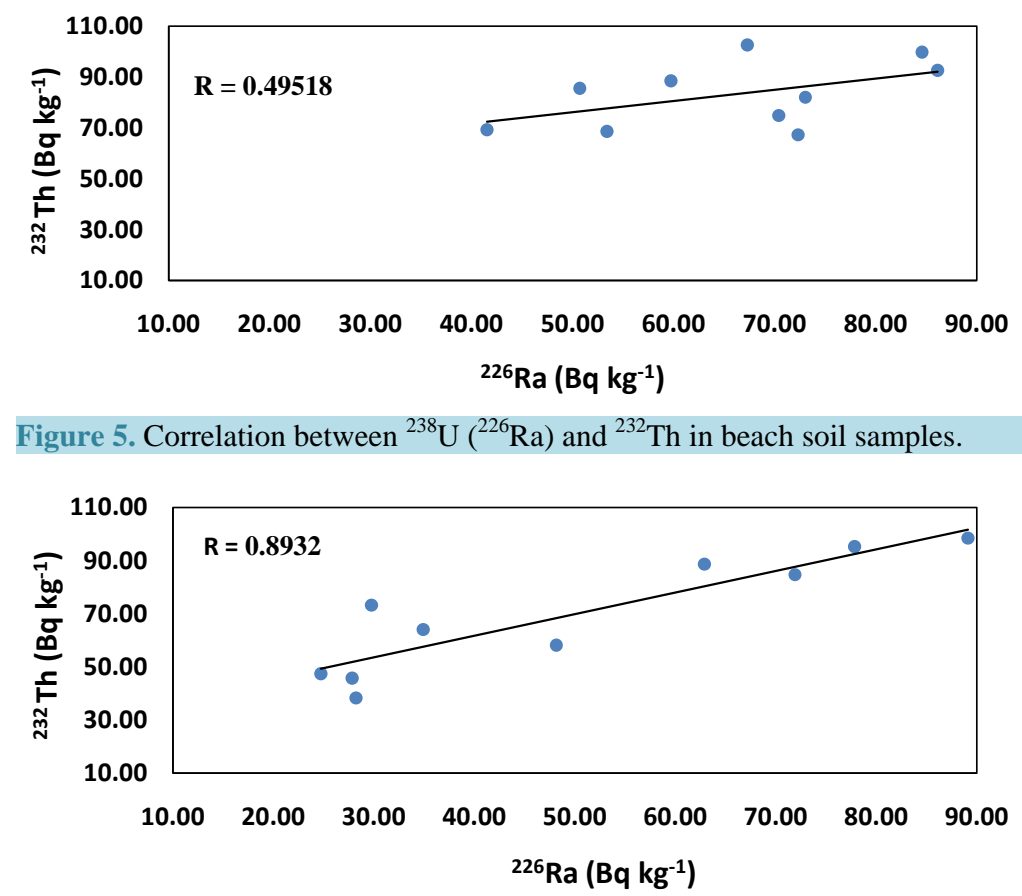

Figure 6. Correlation between ${ }^{238} \mathrm{U}\left({ }^{226} \mathrm{Ra}\right)$ and ${ }^{232} \mathrm{Th}$ in beach sand samples.

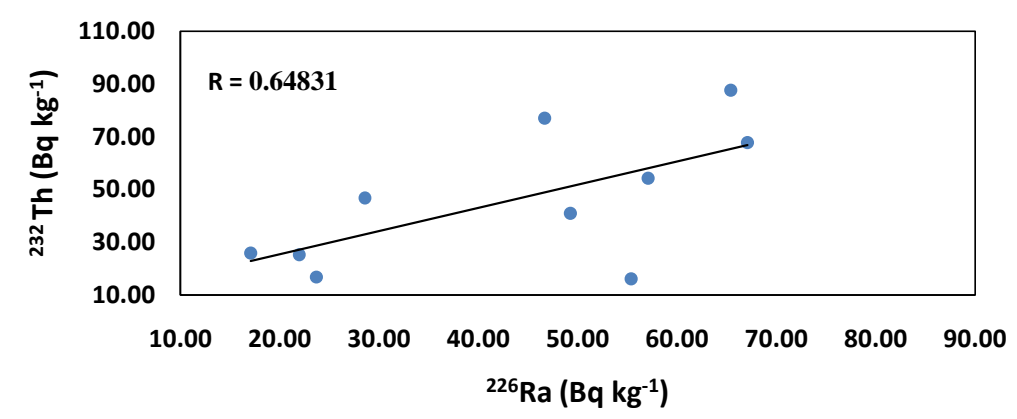

Figure 7. Correlation between ${ }^{238} \mathrm{U}\left({ }^{226} \mathrm{Ra}\right)$ and ${ }^{232} \mathrm{Th}$ in beach sediment samples.

$41.52 \pm 7.27-86.12 \pm 6.72,67.39 \pm 7.45-102.64 \pm 5.68$ and $787.51 \pm 7.56-1125.40 \pm 6.34 \mathrm{~Bq} \cdot \mathrm{kg}^{-1}$, respectively. In most of the soil samples the activity ratios of ${ }^{232} \mathrm{Th}$ and ${ }^{226} \mathrm{Ra}$ are greater than unity, which indicate the higher activity concentration as well as gamma dose rate produced by ${ }^{232} \mathrm{Th}$ rather than that of ${ }^{226} \mathrm{Ra}$. A variation of $24.72 \pm 9.92-89.12 \pm 2.73,38.43 \pm 8.34-98.59 \pm 2.47$ and $401.83 \pm 6.82-649.22 \pm 3.67 \mathrm{~Bq} \cdot \mathrm{kg}^{-1}$ in the radioactivities of the above three radionuclides, respectively, were found in the sand samples. The ${ }^{232} \mathrm{Th} /{ }^{226} \mathrm{Ra}$ ratios of sand samples show the greater concentration of ${ }^{232} \mathrm{Th}$ than that of ${ }^{226} \mathrm{Ra}$. The radioactivities of the above three radionuclides in sediment samples are varied in the range of $17.09 \pm 7.44-67.10 \pm 3.41,16.14 \pm 4.77$ $87.59 \pm 1.99$ and $542.38 \pm 6.75-654.94 \pm 5.36 \mathrm{~Bq} \cdot \mathrm{kg}^{-1}$, respectively. The activity ratios of ${ }^{232} \mathrm{Th}$ and ${ }^{226} \mathrm{Ra}$ showed that the activity concentration of ${ }^{232} \mathrm{Th}$ in most of the sediment samples was higher than that of ${ }^{226} \mathrm{Ra}$. It should be mention that in most of the sediment samples the radioactivities due to ${ }^{40} \mathrm{~K}$ were found below the background level and it may be happened due to the difference in geological properties. Most probably mud of soil contain large amount of ${ }^{40} \mathrm{~K}$, but sediments that are collected from sallow sea water were frequently disturbed by the wave of the sea water and makes clear from the mud and possibly results to lower concentration of ${ }^{40} \mathrm{~K}$.

The comparison of the measured mean specific activities of natural radionuclides among the investigated samples (Figure 4) shows the high activity concentration of ${ }^{226} \mathrm{Ra},{ }^{232} \mathrm{Th}$ and ${ }^{40} \mathrm{~K}$ in soil samples were found than that of sand and sediment samples. Moreover, in account of concentration of radionuclides and hence the gamma dose rate production, the three category soil samples decreasing in ordered as, soil $>$ sand $>$ sediment. 
The correlations between ${ }^{226} \mathrm{Ra}$ and ${ }^{232} \mathrm{Th}$ activities as shown in Figures 5-7 are approximately linear with the correlation coefficients of $0.49,0.89$ and 0.65 in soil, sand and sediment samples respectively.

The presently measured mean values of specific activities of the natural radionuclides ${ }^{226} \mathrm{Ra},{ }^{232} \mathrm{Th}$ and ${ }^{40} \mathrm{~K}$ are compared (Table 2) with the corresponding reported data from different countries [13]-[23]. For the above three radionuclides the worldwide mean values are rather low compared to present investigation. The mean specific activities due to ${ }^{226} \mathrm{Ra}$ obtained in this work are nearer to those for Pakistan and Thailand. The ${ }^{226} \mathrm{Ra}$ activities for Brazil collected in Table 2 are significantly higher and the reason is high mineral deposition in that beach sand of Brazil. The mean values of ${ }^{232} \mathrm{Th}$ activities in $\mathrm{Bq} \cdot \mathrm{kg}^{-1}$ found in this work are comparable to Potenga (75.93) [13], Pakistan (84), Thailand (63.8 and 45) and China (44.9) and a little bit lower than Kuakata [14] (90.56 and 93.72), but much lower than Cox's Bazar (4736.07 and 215.13) [15], India (2825) and Brazil (1735, 6422 and 55,537). The higher content of heavy minerals like Monazite, Kyanite, etc., in the soil/sand of Cox's Bazar, India and Brazil cause this difference. The mean ${ }^{40} \mathrm{~K}$ activities of this work are close to Kuakata, Cox's Bazar, Pakistan and Egypt. The overall mean activities of soil in this investigation are found higher than that of other countries collected in Table 2 and the reasons may be the geological properties of soil and also may be the different kinds of organic and inorganic materials from the food and containers that are left behind by the tourist.

At a glance the ${ }^{226} \mathrm{Ra}$ and ${ }^{232} \mathrm{Th}$ activities found in this investigation indicate the lower deposition of minerals exist in soil, sand and sediment samples collected from the Potenga sea beach area.

Table 2. Comparison of the measured mean specific activities due to natural radionuclides in soil, sand and sediment samples with the values reported for soil and sand of various countries in literature.

\begin{tabular}{|c|c|c|c|c|}
\hline \multirow{2}{*}{ Location } & \multicolumn{3}{|c|}{ Mean specific activity $\left(\mathrm{Bq} \cdot \mathrm{kg}^{-1}\right)$} & \multirow{2}{*}{ References } \\
\hline & ${ }^{226} \mathrm{Ra}$ & ${ }^{232} \mathrm{Th}$ & ${ }^{40} \mathrm{~K}$ & \\
\hline Beach Soil, Potenga, Bangladesh & 65.9 & 83.17 & 946.96 & Present work \\
\hline Beach Sand, Potenga, Bangladesh & 49.52 & 69.49 & 512.19 & Present work \\
\hline Beach Sediment, Potenga, Bangladesh & 43.22 & 45.85 & 594.34 & Present work \\
\hline Beach Soil, Potenga, Bangladesh & 37 & 75.93 & 424 & [13] \\
\hline Beach Soil, Kuakata, Bangladesh & 29.19 & 90.56 & 874.89 & [14] \\
\hline Beach Sand, Kuakata, Bangladesh & 29.48 & 93.72 & 551.24 & [14] \\
\hline Beach Soil, Cox’s Bazar, Bangladesh & - & 36.67 & 458.23 & [15] \\
\hline Beach Sand (Heavy), Cox's Bazar, Bangladesh & - & 4736.07 & 646.34 & [15] \\
\hline Beach Sand (Light), Cox’s Bazar, Bangladesh & - & 215.13 & 300.47 & [15] \\
\hline Orissa, India & - & 2825 & 180 & [16] \\
\hline Peshwar, Pakistan & 65 & 84 & 646 & [17] \\
\hline Chalatat and Samila Beach Songkhal, Thailand & 41.4 & 63.8 & 247.8 & [18] \\
\hline Hatyai District, Songkhla, Thailand & 67.7 & 45 & 213 & [19] \\
\hline Persian Gulf, Iran & 35 & 26 & 395 & [20] \\
\hline Hurgada, Egypt & 20.6 & 22.4 & 548 & [21] \\
\hline Safaga, Egypt & 25.3 & 21.4 & 618 & [21] \\
\hline Xianyang, china & 31.1 & 44.9 & 776 & [22] \\
\hline Porto seguro, Brazil & 313 & 1735 & 25 & [23] \\
\hline Meaipe, Brazil & 1001 & 6422 & 127 & [23] \\
\hline Guarapari, Brazil & 4043 & 55,537 & 63 & [23] \\
\hline Worldwide mean & 33 & 36 & 474 & [12] \\
\hline
\end{tabular}




\subsection{Radium Equivalent Activity, External Hazard Index and Dose Rate}

The radium equivalent activity, external hazard index, gamma dose rate and annual effective dose were calculated from the measured activities of ${ }^{226} \mathrm{Ra},{ }^{232} \mathrm{Th}$ and ${ }^{40} \mathrm{~K}$ and the results are given in Table 3 . The radium

Table 3. Radium equivalent activity $\left(\mathrm{Ra}_{\mathrm{eq}}\right)$, external hazard index $\left(H_{\mathrm{ex}}\right)$, dose rate $(D)$ and annual effective dose calculated from the measured specific radioactivities.

\begin{tabular}{|c|c|c|c|c|}
\hline Sample ID & $\mathrm{Ra}_{\mathrm{eq}}\left(\mathrm{Bq} \cdot \mathrm{kg}^{-1}\right)$ & $H_{\mathrm{ex}}$ & $D\left(\mathrm{nGy}^{-\mathrm{H}^{-1}}\right)$ & Annual effective dose (mSv) \\
\hline \multicolumn{5}{|c|}{ Soil } \\
\hline SB-L-1 & 293.76 & 0.81 & 140.84 & 0.35 \\
\hline SB-L-2 & 241.57 & 0.67 & 114.22 & 0.28 \\
\hline SB-L-3 & 269.28 & 0.75 & 130.63 & 0.32 \\
\hline SB-L-4 & 249.31 & 0.69 & 120.86 & 0.30 \\
\hline SB-L-5 & 287.45 & 0.79 & 135.45 & 0.33 \\
\hline SB-L-6 & 275.61 & 0.76 & 130.01 & 0.32 \\
\hline SB-L-7 & 234.69 & 0.65 & 113.71 & 0.28 \\
\hline SB-L-8 & 235.34 & 0.65 & 112.44 & 0.28 \\
\hline SB-L-9 & 217.46 & 0.61 & 107.14 & 0.26 \\
\hline SB-L-10 & 206.69 & 0.57 & 99.21 & 0.24 \\
\hline Average & 251.12 & 0.70 & 120.45 & 0.30 \\
\hline \multicolumn{5}{|c|}{ Sand } \\
\hline SB-L-11 & 257.82 & 0.71 & 119.75 & 0.29 \\
\hline SB-L-12 & 166.27 & 0.46 & 77.02 & 0.19 \\
\hline SB-L-13 & 129.02 & 0.36 & 61.95 & 0.15 \\
\hline SB-L-14 & 221.29 & 0.61 & 101.31 & 0.25 \\
\hline SB-L-15 & 115.14 & 0.32 & 55.43 & 0.14 \\
\hline SB-L-16 & 170.49 & 0.47 & 81.18 & 0.20 \\
\hline SB-L-17 & 160.43 & 0.44 & 74.84 & 0.18 \\
\hline SB-L-18 & 218.22 & 0.60 & 99.70 & 0.24 \\
\hline SB-L-19 & 275.55 & 0.76 & 127.99 & 0.31 \\
\hline SB-L-20 & 133.20 & 0.37 & 64.46 & 0.16 \\
\hline Average & 184.74 & 0.51 & 86.36 & 0.21 \\
\hline \multicolumn{5}{|c|}{ Sediment } \\
\hline SB-L-21 & 136.48 & 0.38 & 66.06 & 0.16 \\
\hline SB-L-22 & 172.61 & 0.48 & 81.91 & 0.20 \\
\hline SB-L-23 & 236.51 & 0.65 & 110.63 & 0.27 \\
\hline SB-L-24 & 54.14 & 0.15 & 23.55 & 0.06 \\
\hline SB-L-25 & 107.80 & 0.29 & 47.48 & 0.12 \\
\hline SB-L-26 & 164.03 & 0.44 & 71.94 & 0.18 \\
\hline SB-L-27 & 47.86 & 0.13 & 21.15 & 0.05 \\
\hline SB-L-28 & 58.07 & 0.16 & 25.40 & 0.06 \\
\hline SB-L-29 & 78.46 & 0.21 & 35.34 & 0.09 \\
\hline SB-L-30 & 156.77 & 0.42 & 68.07 & 0.17 \\
\hline Average & 121.27 & 0.33 & 55.15 & 0.14 \\
\hline
\end{tabular}


equivalent activity $\left(\mathrm{Ra}_{\text {eq }}\right)$ in all investigated samples varied from 47.86 to $293.76 \mathrm{~Bq} \cdot \mathrm{kg}^{-1}$ and these values are less than $370 \mathrm{~Bq} \cdot \mathrm{kg}^{-1}$, which are acceptable for safe use [24]. In this study area, the external hazard index $\left(H_{\mathrm{ex}}\right)$ obtained is in the range of $0.13-0.81$. Since these values are lower than unity, the radiation hazard in the investigated area is also considered as low. The mean value of absorbed dose rate in soil and sand samples amounting to 120.45 and $86.36 \mathrm{nGy} \cdot \mathrm{h}^{-1}$, respectively, are higher than the world population-weighted mean value of the outdoor absorbed dose rate in air $\left(59 \mathrm{nGy} \cdot \mathrm{h}^{-1}\right)$ [12]. The calculated average values of annual effective dose in soil, sand and sediment samples are $0.30,0.21$ and $0.14 \mathrm{mSv}$, which are rather high than the world population-weighted annual effective dose average $0.07 \mathrm{mSv}$ [12].

\section{Conclusion}

The distribution of natural radionuclides in soil, sand and sediment samples collected from Potenga sea beach area of Chittagong, Bangladesh was analyzed by HPGe $\gamma$-ray spectrometry. Among the investigated samples, soil has the higher mean specific radioactivities of ${ }^{226} \mathrm{Ra},{ }^{232} \mathrm{Th}$ and ${ }^{40} \mathrm{~K}$, and $\mathrm{Ra}_{\mathrm{eq}}$ values as well as dose rate and most probably due to manipulation of tourism. The study also indicates that the analyzed soil, sand and sediment samples have lower deposition of minerals. No peak at $661 \mathrm{keV}$ from the decay of ${ }^{137} \mathrm{Cs}$ activity was found in the spectrum. However, the results of radiation hazard indices reflect that the investigated area of Potenga sea beach seems to be radiologically safe for human being.

\section{Acknowledgements}

The authors would like to acknowledge the help of the authority of University and Atomic Energy Centre for providing various facilities.

\section{References}

[1] International Atomic Energy Agency (IAEA) (2003) Guidelines for Radioelement Mapping Using Gamma Ray Spectrometry Data. IAEA Technical Report Series, No. 1363, Vienna.

[2] Wilson, W.F. (1994) A Guide to Naturally Occurring Radioactive Material (NORM). Pennwell Publishing Company, USA.

[3] United Nations Scientific Committee on the Effects of Atomic Radiation (UNSCEAR) (1993) Sources and Effects of Ionizing Radiation, Report to General Assembly, with Scientific Annexes. New York.

[4] Bernard, Z. (1995) Tracers in the Oil Field. Elsevier, Amsterdam.

[5] National Council on Radiation Protection and Measurements (NCRP) (2006) Ionizing Radiation Exposure of the Population of the United States. NCRP Report, No. 160, Maryland.

[6] Amekudzie, A., Emi-Reynolds, G., Faanu, A., Darko, E.O., Awudu, A.R., Adukpo, O., Quaye, L.A.N., Kpordzro, R., Agyemang, B. and Ibrahim, A. (2011) Natural Radioactivity Concentrations and Dose Assessment in Shore Sediments along the Coast of Greater Accra, Ghana. World Applied Sciences Journal, 13, 2338-2343.

[7] Debertin, K. and Helmer, R.G. (1980) Gamma and X-Ray Spectrometry with Semiconductor Detectors. Elsevier, Amsterdam.

[8] Schőtzig, U. and Debertin, K. (1983) Photon Emission Probabilities per Decay of ${ }^{226}$ Ra and ${ }^{232}$ Th in Equilibrium with Their Daughter Products. Applied Radiation and Isotopes, 34, 533-538. http://dx.doi.org/10.1016/0020-708X(83)90275-2

[9] Knoll, G.F. (1989) Radiation Detection and Measurement. John Wiley \& Sons, Inc., New York.

[10] International Atomic Energy Agency (IAEA) (1987) Radiometric Reference Materials; RGU-1, RGTh-1 and RGK-1. IAEA Report No. RL/148. Vienna.

[11] Beretka, J. and Mathew, P.J. (1985) Natural Radioactivity of Australian Building Materials, Industrial Wastes and By-Products. Health Physics, 48, 87-95. http://dx.doi.org/10.1097/00004032-198501000-00007

[12] United Nations Scientific Committee on the Effects of Atomic Radiation (UNSCEAR) (2000) Sources and Effects of Ionizing Radiation. Report to General Assembly, with Scientific Annexes, New York, 91-125.

[13] Ghose, S., Kamal, M., Chowdhury, M.I., Alam, M.N. and Islam, M.N. (2003) Gamma Radiation Dose from the Naturally Occurring Radionuclides in Soil of the Potenga Sea Beach of Bangladesh. Nuclear Science and Applications, 12, 31-36. 
[14] Nazrul Islam, K.M., Paul, D., Rahman Bhuiyan, M.M., Akter, A., Neher, B. and Azharul Islam, S.M. (2012) Study of Environmental Radiation on Sand and Soil Samples from Kuakata Sea Beach of Patuakhali. Journal of Environmental Protection, 3, 1078-1084. http://dx.doi.org/10.4236/jep.2012.39126

[15] Ansary, M.M. (1997) Study of Radioactivity in Beach Sand Minerals and Soils for the Estimation of Radiation Dose. M.Sc. Thesis, Chittagong University, Bangladesh.

[16] Mohanty, A.K., Sengupta, D., Das, S.K., Vijayan, V. and Saha, S.K. (2004) Natural Radioactivity in the Newly Discovered High Background Radiation Area on the Eastern Coast of Orissa, India. Radiation Measurements, 38, $153-165$. http://dx.doi.org/10.1016/j.radmeas.2003.08.003

[17] Ali, S., Tufail, M., Jamie, K., Ahmed, A. and Khan, H.A. (1996) Gamma-Ray Activity and Dose Rate of Brick Samples from Some Area of North West Frontier Province (NWFP), Pakistan. Science of Total Environment, 187, $247-252$. http://dx.doi.org/10.1016/0048-9697(96)05109-1

[18] Benjakul, S. (2007) Natural Radionuclide Distribution in Soil from Muang District in Songkhla Province. M.Sc. Thesis, Thaksin University, Songkhla.

[19] Kessaratikoon, P. and Awackechi, S. (2008) Natural Radioactivity Measurement in Soil Samples Collected from Municipal Area of Hat Yai District in Songkhla Province, Thailand. KMITL Science Technology Journal, 8, 52-58.

[20] Abdi, M.R., Kamali, M. and Vaezifar, S. (2008) Distribution of Radioactive Pollution of ${ }^{238} \mathrm{U},{ }^{232} \mathrm{Th},{ }^{40} \mathrm{~K}$ and ${ }^{137} \mathrm{Cs}$ in Northwestern Coasts of Persian Gulf, Iran. Marine Pollution Bulletin, 56, 751-757. http://dx.doi.org/10.1016/j.marpolbul.2007.12.010

[21] El-Arabi, A.M. (2005) Natural Radioactivity in Sand Used in Thermal Therapy at the Red Sea Coast. Journal of Environmental Radioactivity, 81, 11-19. http://dx.doi.org/10.1016/j.jenvrad.2004.11.002

[22] Lu, X. and Zhang, X. (2008) Measurement of Natural Radioactivity in Beach Sands from Rizhao Bathing Beach, China. Radiation Protection Dosimetry, 130, 385-388. http://dx.doi.org/10.1093/rpd/ncn053

[23] Veiga, R., Sanches, N., Anjos, R.M., Macario, K., Bastos, J. and Iguatemy, M. (2006) Measurement of Natural Radioactivity in Brazilian Beach Sands. Health Physics, 41, 189-196.

[24] Nuclear Energy Agency (NEA) Group (1979) Exposure to Radiation from Natural Radioactivity in Building Materials. OECD, Rue Andre-Pascal, Paris. 
Scientific Research Publishing (SCIRP) is one of the largest Open Access journal publishers. It is currently publishing more than 200 open access, online, peer-reviewed journals covering a wide range of academic disciplines. SCIRP serves the worldwide academic communities and contributes to the progress and application of science with its publication.

Other selected journals from SCIRP are listed as below. Submit your manuscript to us via either submit@scirp.org or Online Submission Portal.
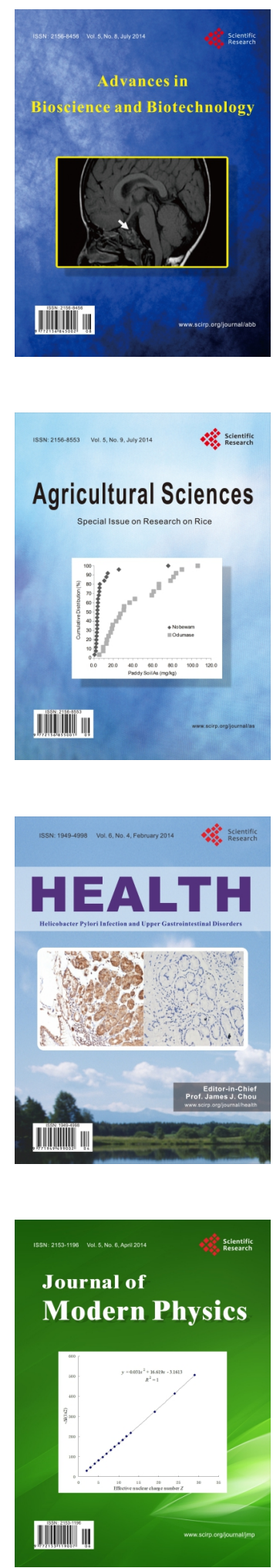
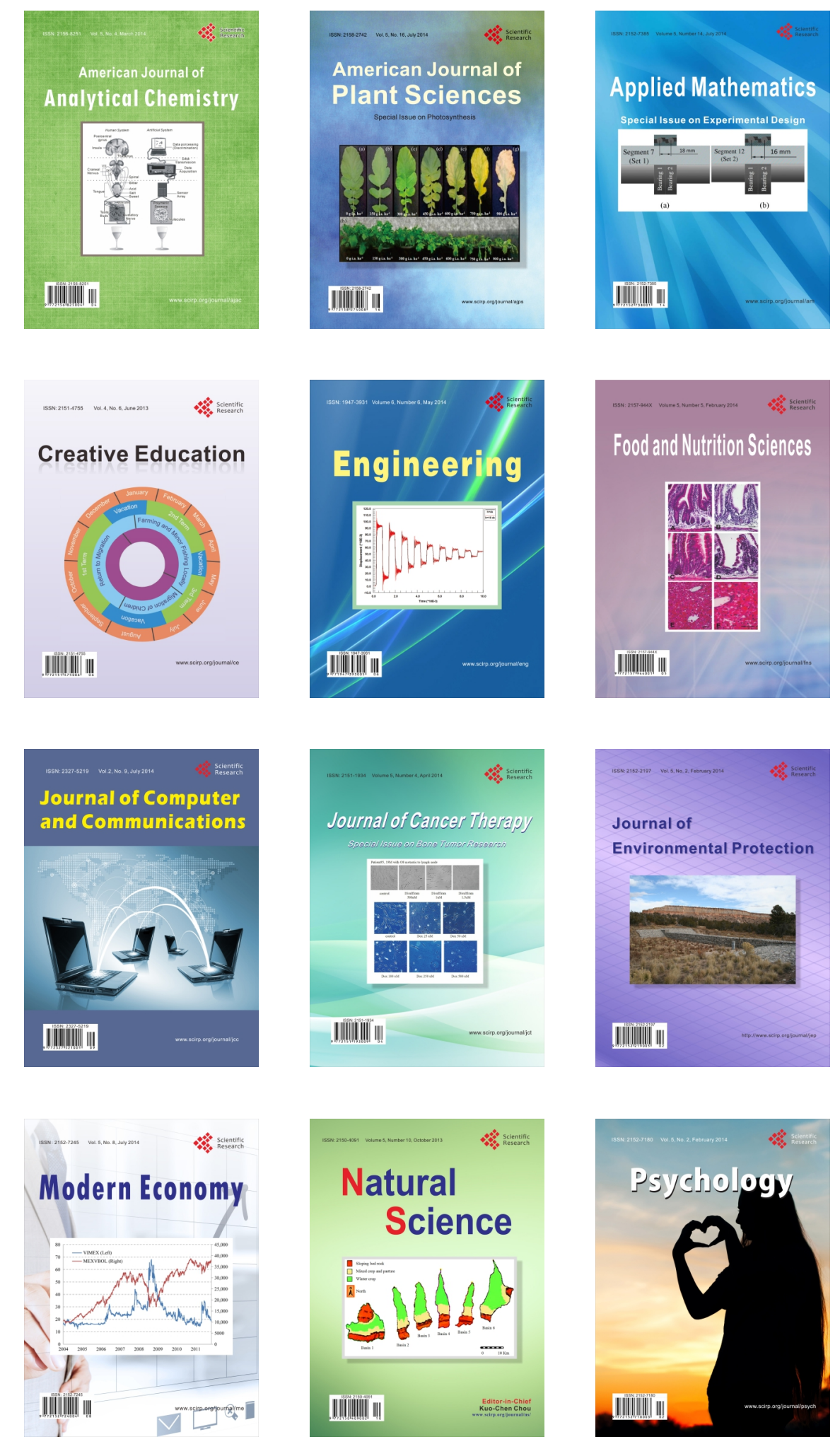